\title{
Northwest Journal of Teacher Education
}

Volume 1

Issue 1 Northwest Passage: Journal of

Educational Practices

Article 6

January 2001

\section{Linking Children's Literature with Mathematics Instruction}

Judy Schroeder

Betz Elementary School

Jane Liu

Eastern Washington University

Follow this and additional works at: https://pdxscholar.library.pdx.edu/nwjte

Part of the Education Commons

Let us know how access to this document benefits you.

\section{Recommended Citation}

Schroeder, Judy and Liu, Jane (2001) "Linking Children's Literature with Mathematics Instruction," Northwest Journal of Teacher Education: Vol. 1 : Iss. 1 , Article 6.

DOI: https://doi.org/10.15760/nwjte.2001.1.1.6

This open access Article is distributed under the terms of the Creative Commons Attribution-NonCommercialShareAlike 4.0 International License (CC BY-NC-SA 4.0). All documents in PDXScholar should meet accessibility standards. If we can make this document more accessible to you, contact our team. 


\title{
Linking Children's Literature with Mathematics Instruction
}

\author{
Judy Schroeder \\ Betz Elementary School
}

\author{
Jane Liu, Ph.D. \\ Eastern Washington University
}

\begin{abstract}
The purpose of this study was to experiment and analyze the effectiveness of children's literature in promoting mathematics learning in a second grade classroom. The focus of this project was to address the following questions: How does children's literature help with mathematics understanding? To what extent does the literature help students increase interest in mathematics? What possible impact does integrating the literature have on students 'mathematics achievements?
\end{abstract}

\section{INTRODUCTION}

There is a national concern about mathematical competence of our youth (Whitin and Wilde, 1992). Students' attitudes toward their competency appear to rapidly decline as they pass the fourth grade. It seems that we have raised students who arc more competent at pushing symbols, but less successful in solving problems and "leave school with a bad taste for mathematics" (Whitin \& Wilde, 1992, p. 23). One of the main reasons for the phenomenon is that mathematics instruction is traditionally isolated from other subjects and real life situations. Instruction relies heavily on texts, workbooks, teacher's explanation, memorization of facts and algorithms, and paper-pencil drill. With the exception of the concepts of money and time, mathematics seems to have littlc application for children in their daily lives; therefore, students have a difficult time transferring mathematical learning to real life problems or solutions.

Children must find mathematical experiences interesting if they are to achieve their mathematical potentials. Using literature as a springboard has bcen perceived as one way to capture children's interest (Welchman-Tischler, 1992). With literature, a teacher is able to introduce a math concept in a manner that students fecl familiar and comfortable. This approach can help to relieve math anxiety that many children experience when being introduced to a new mathematical concept (Whitin \& Wildc, 1992). Children enjoy listening to stories. A teacher can take advantage of this inclination and create a non-threatening experience for the introduction of a new math concept. Stories in literature also provide a variety of situations that help teach children how to deal with conflict, how to share with each other, how to get along well and help others, and how to take responsibility. Along with the moral lessons in a story, children can learn incidentally about mathematics without being aware of it (Lightsey, 1990). Take Eating Fractions (mcMillan, 1991) as an example. Through the story, students can see children in the book dividing food into equal parts and begin to understand that fractions are parts of a whole. 


\section{PURPOSE OF STUDY AND RESEARCH QUESTIONS}

Rescarch indicated that using children's literature in teaching mathematics contributed to reduced math anxiety among students and better linkage of real world mathematics with classroom math concept learning (Burnett \& Wichman, 1997; Carlson, Floto \& Mays, 1997; \& Hong, 1996). Educational practice that integrates children's literature into mathematics instruction has becn carried out for approximately a decade. This strategy, howevcr, is not widely used. The purpose of this study was to experiment and analyze the effectiveness of children's literature in promoting mathematics learning in a second grade classroom. The focus of this project was to address the following questions: How does children's literature help with mathematics understanding? To what extent does the literature help students increase interest in mathcmatics? What possible impact does integrating the literature have on students' mathematics achievements?

\section{THE PROJECT DESIGN}

The participants in this project consisted of one second grade classroom of 20 students. The school is located in a community where there are five elementary schools, one middle school, one high school and one state university. Of the 20 students, 12 were boys and 8 were girls; $55 \%$ were eligible for free and/or reduced lunch program; 17 were Caucasian, 2 were Hispanics and 1 was African American.

The curriculum was designed to integrate children's storybooks with a traditional mathematics basal program, Heath Mathematics Connections (Manfre, Moser, Lobato, \& Morrow, 1992). Manipulatives and workbooks that accompany Heath Mathematics Connections basal were also used. The unit focused on the chapter "Addition and Subtraction Facts through 12", which introduces strategies of doubles, joining sets, counting on missing addends, number patterns, ordering, separating sets, and counting backward and forward using a number line. It was a four-week unit, including a math skill pre- test, followed with nine lessons, a mid-chapter test, eight more lessons, end of chapter test and math skill post-test at the end of the unit. The pre and post math skills test were modified from a math skills survey developed by Burnett and Wichman (1997). In addition, students were required to keep a math journal practicing the language of math concepts to be taught.

The learning environment was arranged as group clusters. The students sat in a group of three to five facing each other. This allowed for effective use of time when cooperative activities took place. In the classroom there was a math basket of approximately 20 books of children's literature relating to math concepts to be taught along with the books that had been used in instruction. The students were encouraged to read the books during silent reading time. Availability of the books aimed at offering students more opportunities to explore the wonders of mathematics and to enable them to see its validity in a real world. The following is a list of sample free-choice reading books in the basket chosen by the teacher (Please see the References for a comprehensive reading list):

A Dozen Dozens, Harriet Ziefert

Monster Math, Grace Maccarone

How Many Fish? Caron Lee Cohen

Sea Sums, Joy N. Hulme

One Gorilla, Atsuko Morozumi

The Button Box, Margarete S. Reid

My Little House 1,2,3, Laura Ingalls Wilder Deep Down Underground, Olivier Dunrea Ten Terrible Dinosaurs, Paul Stickland

How Many Snails? Paul Giganti, Jr.

The sequence of daily activities varied, based on student learning needs and focus of the learning. Not every lesson designed from the math basal, Heath Mathematics was accompanied with a piece of literature. The teacher took every precaution to not impose a piece of literature upon math concept learning. Research cautioned against such a practice by forcing literature to "fit" every math concept to be taught (Griffith \& Clyne, 1988). Instead, the math concept should flow from the literature.

An example of a daily routine learning process was as follows. A class started with children's litcrature to introduce or reinforce a 
mathematical concept. Students sat on a carpet in front of the classroom to listen to the story, and then participated in the discussion of the story. To incrcase the students' ability to communicate mathematically, students were asked to return to their seats and write in their journals using the math vocabulary. The guided instruction time followed for students to practice the math concept(s) using manipulatives that could tie with the literature and math concept(s), or to reenact a story and/or new activities that would help deepen their peers' understanding of the concept(s). At the end of a lesson, the students were engaged independently in practicing math concept(s) using manipulatives and/or worksheet.

The literature and activities were chosen to help the students become aware of the fact that mathematics was useful when related to real life situations. Children's stories served as a basis for meaningful context which facilitated students' mathematical comprehension. Reading a piece of literature provided students with a familiar background upon which they built their comprehension of the math concept(s) and made a connection between the math concept(s) and their real-life world.

A homework schedule was used every Tuesday and Thursday for reinforcement of the learned math concepts. Students returned their homework the following day.

The students' learning was observed and the teacher took anecdotal notes daily. Results from tests and math skills pre-and post-tests were used to reflect the effectiveness of this project. The daily summative evaluation occurred after assessing students' daily assignments. If a student showed signs of struggling with a concept, the teacher would give him/her individual attention using the silent reading time to help the student for a better understanding of the concept. A rubric for testing results was $96-100 \%$ exceeded standard (E), 80-95\% met standard (S) and below $80 \%$ did not meet standard $(\mathrm{N})$.

\section{THE PROJECT IMPLEMENTATION}

The time frame designated for this project in the daily schedule was from 10:15 to $10: 55$
Monday through Friday. Students returned from recess prior to the math class and lunchtime followed at 11:00 a.m. Being aware of the time constraint for the project, the teacher had students make every necessary preparation prior to the recess time, i.e., getting out math journals, putting math worksheets on desks, or setting manipulatives required for the math lesson on desks. In addition, the teacher gave instruction for what the students would be doing in math prior to dismissal for recess. In order to "buy time" for instruction, the teacher sometimes had students write in their math journal or finish independent seat work during silent reading time, which occurred after lunch recess.

In the first half of the unit, eight lessons out of nine used children's literature to connect mathematical concepts. In the second half, five out of eight lessons incorporated literature in the mathematics instruction. It was difficult to find literature that addressed both addition and subtraction facts through 12 in the same book. In learning order property and counting on strategy, students explored the book Domino Addition by Lynette Long (1996). The book Mission Addition by Loreen Leedy (1997) was used to introduce the meaning of addition facts through 12. The setting of the story was a classroom with Miss Prime as the teacher. The illustrations were bright, colorful and inviting to the students. The format of the story introduced the language of addition and attracted students to participate in a detective case searching for clues. The clues produced addition sentences that made sense to students. After the book was read and discussed, the teacher recreated the scene from the story using her students' names and providing math problems for the students to solve. Sequentially, the students used the math vocabulary in their journal writing. In learning subtraction, M \& M's Counting Book (Barbieri, 1994) was accompanied with real $M$ \& $M$ chocolates. The manipulative increased the students' interest in learning and assisted in making a connection from the concrete to the abstract in student learning. When the story Elevator Magic (Murphy, 1997) was read, the students were quite excited to use their "elevator number lines" to do their math. Often times the teacher overheard students com- 
menting on how fun mathematics was. In Mission Addition (Leedy, 1997)), several students competed to solve the "detective problems" in the story. These problems were directly related to the mathematical concepts addressed in the lesson. The book, Dealing with Addition (Long, 1998), motivated students in learning how to add more than two numbers.

The formative evaluation was conducted on a daily basis. Ancedotal records were used to document students' performance and responses to cach lesson. The project apparently produced a positive effect on students' mathematics achievements. The mean for the pre-test was $76 \%$ and for the post-test was $94 \%$. In addition, the instructor observed an enthusiasm and excitcment developed among the students with the decreased math anxiety as the project progressed. Many students wanted to know first thing in the morning what would be done in the math class that day. When the time came to solve math problems, the students could answer the math questions when they were tied to literature or literature activitics. Many students were eager to solve problems related to the literature. Their intercst also led them to application of what they had learned into problem solving independently.

The principal of the school observed the lesson on studying the mathematical concept of adding three addends using the book Dealing with Addition (Long, 1996). She commented in an obscrvation report, "The students were very motivated by this activity and attended to the task very quickly. The success of the students was dircctly related to the background knowledge they had gained through previous activities, teacher modcling and the teacher's use of the book."

Despite the teacher's caution, a few times the literature used didn't appear to fit well in a math concept, resulting in students' confusion rather than supporting their understanding of the concept. For example, when the book The Doorbell Rang was used to teach using doubles to add, there was not an obvious association between the literature and the mathematical conccpt. With time running out, the tcacher was unable to facilitate students' exploration of the relationship between the story and the math- ematical concept.

\section{CONCLUSION \& RECOMMENDATIONS}

Integration of literature into mathematics instruction was a successful experience for all the students in the project. When using children's literature to introduce math concepts, learning became more applicable to the students in their own lives. The illustrations and stories in the books helped the students visualize the problems. Combination of children's literature and math concepts in a lesson benefited students in increased interest and academic achievements. Owing to the combined activities derived from both the children's literaturc and mathematics learning in one lesson, time constraint might be a concern in implementing such a project. These lessons require time to allow students to investigate, analyze and connect math concepts with the literature. For a successful accomplishment of the project, a teacher should grant an adequate time length for the learning process to happen. Finding an appropriate book to fit a math concept is always a challenging task for a teacher. Thus the teacher needs to broaden resources on what can be used for such a project. The obvious improvement in students' learning encourages the teacher to continue this approach in mathematics instruction.

\section{REFERENCES}

Burnett, S. J., \& Wichman, A. M. (1997). Mathematics and literature: An approach to success. Chicago, IL: Action Research Project, Saint Xavier University. (ERIC Documentation Reproduction Service No: ED 414 567).

Carlson, A.; Floto, D.; \& Mays, B. (1997). Using children's literaturc to develop and advance problem solving and critical thinking in mathematics. Chicago, IL: Action Research Project, Saint Xavier Univcrsity. (ERIC Documentation Reproduction Service No: ED 410 583).

Cuevas, g. J. (1995). Empowering all students to learn mathematics. Prospects for School Mathcmatics. 62-67. Reston, VA: Na- 
tional Council of Teachers of Mathematics.

Gailey, S. K. (1993). The mathematics Children's literature connection. Arithmetic tcacher, 40, 258-261.

Griffith, R., \& Clyne, M. (1988). Books you can count on: Linking mathematics and literature. Portsmouth, NH: Heinemann.

Hong, H. (1996). Effects of mathematics lcarning through children's literature on math achievement and dispositional outcomes. Early Childhood Research Quarterly, 11, 477-494.

Lightsey, G. E. (1996). Using literature to build first grade math concept. Reading Horizons, 36(5), 412-418.

Manfre, E., Moser, J.; Lobato, J., \& Morrow, L. (1992). Heath mathematics connections: Teacher's edition. Washington, D.C.: Heath \& Company.

Welchman-Tischler, R. (1992). How to use children's literature to teach mathematics. Reston, VA: The national Council of Teachers of Mathematics, Inc.

Whitin, D., \& Wilde, S. (1992). Read any good math lately? Portsmouth, NH: Heinemann.

\section{CHILDREN'S LITERATURE USED}

Axelrod, A. (1997). Pigs in the Pantry. New York, NY: Scholastic.

Berenstain, S.J. (1969). Bears on Wheels. New YorK; Random House.

Burns, M. (1997). Spaghetti and Meatballs for All: A mathematical Story. New York: Scholastic Inc.

Calmenson, S. (1984). Ten Furry Monsters. New York: Parents Magizinc press.

Cohen, C. L. (1998). How Many Fish? USA: Harpercollins Publishers.

Dunrea, O. (1989). Deep Down Underground. New York, NY: MacMillan Publishing.
Giganti, P. Jr. (1992). Each Orange Had 8 Slices. New York: Scholastic Inc.

Giganti, P. Jr. (1988). How Many Snails? New York, NY: Greenwillow Books.

Hulme, J. N. (1996). Sea Sums. New York: Hyperion Books.

Bradbury, L. (1975). Counting 0123456789. Lewiston, Maine: Ladybird

Leedy, L. (1997). Mission: Addition. New York, NY: Scholastic, Inc.

Long, L. (1996). Domino Addition. Watertown, Maine: Charlesbridge Publishing.

Maccarone, G. (1995). Monster Math. New York: Scholastic Inc.

McGrath, B. (1994). M \& M counting book. Watertown, Maine: Charlebridge Publishing.

McMillan, B. (1991). Eating Fractions. New York: Scholastic Inc.

Morozumi, A. (1990). One Gorilla. Farrar.

Murphy, S. (1999). Jump, Kangaroo, Jump! New York, NY: HarperCollins.

Murphy, S. (1998). Animals on Board. New York, NY: Harper-Collins Publishers.

Murphy, S. (1997). Elevator Magic. New York, NY: Harper-Collins Publishers.

Murphy, S. (1997). Too Many Kangaroo Things to do. New York: Scholastic Inc.

Myller, R. (1990). How Big Is A Foot? New York, NY: Bantam Doubleday Dell.

Pallotta, J. (2000). Reese's Pieces. New York: Scholastic Inc.

Pallotta, J. (2000). The Hershey's Milk Chocolate Fractions Book. New York: Scholastic Inc.

Reid, M. S. (1990). The Button Box, New York, NY: Dutton Children's Book.

Schlein, M. (1996). More Than One. New York: Scholastic Inc. 
Stickland, P. (1997). Ten Terrible Dinosaurs. New York, NY: Dutton Children's Book.

Schwartz, D. M. (1985). How Much is a Million? New York: Scholastic Inc.
Ziefert, H. (1998). A dozen dozens. USA: Viking.

Ziefert, H. (1985). A dozen dogs. New York, NY: Random House.

Wilder, L. I. (1997). My Little House 1, 2 , 3. USA: Harpercollins.

Ms. Judy Schroeder ia a teacher at Betz Elementary School in Cheney, Washington 99004.

Dr. Jane Liu is an associate professor in the Department of Education at Eastern Washington University, Cheney, Washington 99004. Email: Jane.Liu@mail.ewu.edu 